\title{
Philip Pettit, Just Freedom. A Moral Compass for a Complex World
}

\author{
Bertjan Wolthuis
}

Philip Pettit, Just Freedom. A Moral Compass for a Complex World (New York: W.W. Norton \& Company, 2014), $258 p$.

Met de titel van dit boek geeft Philip Pettit niet alleen aan dat vrijheid rechtvaardig moet worden verdeeld, maar ook dat we aan één politiek ideaal wel genoeg hebben: alleen vrijheid. Maar dat vrijheidsbegrip moet dan wel republikeins worden ingevuld. Pettit zet zich in dit boek af tegen de opvatting van vrijheid die zowel het klassieke liberalisme als het libertarisme hanteert - Isaiah Berlin noemde haar 'negative liberty' - en die nog steeds doorwerkt in bijvoorbeeld het welfare liberalism van Rawls.

Wat houdt de republikeinse vrijheid precies in? Pettit legt uit dat de liberale traditie, die eigenlijk nog heel jong is, vrijheid beschouwt als vrijheid van bemoeienis ('non-interference'). Hij gebruikt het beeld van een ruiter op een paard: de liberaal heeft als ideaal dat de teugels loshangen. Met de burger (het paard dus) moet de staat of de medeburger zich niet bemoeien; het paard moet zijn eigen weg kunnen kiezen. Het republikanisme, een gedachtegoed met een veel langere geschiedenis, is rigoureuzer en wil dat er niemand op het paard zit. Je bent niet vrij als je weet dat er een ruiter is die de teugels aan zou kunnen trekken. Het republikeinse vrijheidsideaal is afwezigheid van overheersing ('non-dominance'). Een ieder moet zijn eigen heer zijn.

Het beeld is mooi gevonden - op de kaft van het boek prijkt een bronzen paard maar waar het op aankomt is hoe het in de praktijk gestalte kan krijgen en of het dan ook echt verschilt van het liberale ideaal. Pettit legt uit dat in het oude Rome vrijheid werd gekoppeld aan een juridische status: je bent vrij als je niet ondergeschikt bent aan een ander (dominium) en als je invloed kunt uitoefenen op de regels die voor jou zullen gaan gelden (imperium). De republikeinse vrijheid beperkt zich nadrukkelijk dus niet tot het strikt politieke terrein alleen: ook op sociaal en economisch vlak verdraagt vrijheid zich niet met overheersing (door bijvoorbeeld een echtgenoot (in het geval van een vrouw) of een meester (in het geval van een slaaf)). Het republikeinse vrijheidsideaal, dat in de praktijk alleen bereikbaar was voor een elite, wordt van oudsher gekoppeld aan een gemengde constitutie waarin burgers het recht hebben het bestuur te controleren en beslissingen aan te vechten.

Pettit laat zien dat de republikeinse gemengde constitutie en het bijpassende vrijheidsbegrip op verschillende manieren werden ondermijnd. In de eerste plaats door Rousseau, die vrijheid weliswaar republikeins opvat als vrijheid van over- 
heersing, maar die dit vrijheidsbegrip in de praktijk lijkt te ondergraven door burgers over te leveren aan de heerschappij van het volk, waarvan een meerderheid steeds kan claimen de algemene wil te hebben gevolgd. Rousseau breekt radicaal met de realistische traditie waarvan Machiavelli het voorbeeld is, door de republikeinse constitutie niet langer te beschouwen als een gemengde staatsvorm, waarin de verschillende bevolkingsgroepen de macht delen, elkaar in evenwicht houden en controleren. Pettit is ervan overtuigd dat met die staatsvorm de vrijheid van overheersing het beste gediend is. Een tweede aanval schrijft Pettit op het conto van Bentham, die vanwege zijn radicale hervormingsagenda een veel terughoudender vrijheidsbegrip nodig had. Pettit speculeert: 'Were Bentham to have called for universal freedom as non-domination, then he would have had to advocate the transformation of family law, under which a husband had power over his wife, and master-servant law, under which an employer had power over his employees. [...] I suspect that as he began to think about what freedom as non-domination for all would require, the traditional conception began to seem too radical and the novel conception looked like the only feasible and appealing ideal' (p. 15-16). Een beslissende slag kreeg het republikanisme te verduren van wat we nu beschouwen als klassieke liberalen, die in de overgang naar een industriële economie de vrijheid om contracten te sluiten zó onbegrensd maakten, dat de partijen de condities die traditioneel aan contracten vastzaten en waardoor beide partijen een zekere zelfstandigheid behielden, nu naar believen konden herzien, zodat de weg vrij werd gemaakt voor de vrijwillige uitlevering van grote groepen arbeiders aan de industriële elite. In de begindagen van het kapitalisme wordt zo in de praktijk duidelijk, volgens Pettit, wat het verschil is tussen het liberale 'to be let alone' en het republikeinse 'to be secured against the powers of others.' Het republikanisme vat vrijheid op als iets dat pas door een bepaalde organisatie van de politieke samenleving kan ontstaan, omdat vrijheid een relatief begrip is: je bent vrij wanneer de wetten jou op gelijke voet plaatsen met de anderen, zowel in de sociale, de economische als de strikt politieke sfeer. Het liberalisme en het libertarisme daarentegen vatten vrijheid op als iets natuurlijks, dat aan de politieke samenleving voorafgaat en waar de staat dus ook altijd een inbreuk op maakt.

Het historische deel maakt zo mooi duidelijk waarom het werk van Pettit nodig is: het republikeinse gedachtegoed is verslagen door in het bijzonder het liberalisme en gaat daar sindsdien achter verborgen - Pettit spreekt van een 'eclipse.' In twee hoofdstukken legt Pettit uit wat een keuze echt vrij maakt en op welke terreinen vrije keuze benodigd is. In het laatste deel van het boek werkt Pettit de beleidsvoorstellen uit waartoe het republikanisme aanleiding geeft, op het vlak van sociale en politieke rechtvaardigheid en op het terrein van het internationale recht. Ik noem hier enkele van die beleidsvoorstellen.

Omdat het republikanisme inhoudt dat burgers op gelijke voet met elkaar moeten kunnen staan, is het nodig dat burgers zeker zijn van hun bestaan, bijvoorbeeld door middel van een basisinkomen ('basic income,' zoals Van Parijs dat heeft verdedigd). Pettit sluit wat dit punt betreft ook aan bij het werk van Sen en Nussbaum over 'basic capabilities.' Op politiek vlak verdedigt Pettit een gemengde constitutie (met kiesplicht! (p. 147)) omdat die de burgerlijke vrij- 
heden het beste verdedigt, tegen meerderheidstirannie en misbruik van macht door een elite. Gekozen volksvertegenwoordigers moeten bijdragen aan het proces van wetgeving, maar burgers moeten ook zelf de mogelijkheid hebben om op allerlei manieren politieke misstanden aan de kaak te stellen. Wie Machiavelli's Discorsi ernaast legt, zal weinig inhoudelijke verschillen kunnen vinden tussen Pettits gemengde constitutie en dat van zijn grote voorganger. Op internationaal terrein vraagt Pettit aandacht voor private overheersing door non-gouvernementele organisaties en om mogelijkheden om ook hier in verzet te komen tegen onderdrukkende regelingen en praktijken.

Pettits boek is voor iedereen die nog niet zo goed is ingevoerd in de republikeinse staatsopvatting vooral een goed gelukte eye opener. Het zet in algemene termen uiteen hoe de standaardopvatting van vrijheid door en door liberaal is en dat deze opvatting een relatief recente en uiteindelijk ook beperkte notie van vrijheid is. Het republikanisme wordt door Pettit heel geduldig uit de doeken gedaan. Hij daalt zonder zichtbare tegenzin af naar het concrete beleidsniveau en bespreekt de voordelen die zijn voorstellen hebben boven die van (vooral) liberale en libertaristische makelij. Just Freedom biedt een helder geordend overzicht van Pettits republikanisme en vormt daarmee ook een geschikt beginpunt om de rijke hedendaagse literatuur over het republikanisme, inclusief Pettits oeuvre zelf, nader te verkennen.

Wellicht is een minpunt: het ontbreken van een rationele, filosofische onderbouwing van het republikanisme. Waar Habermas de deliberatieve democratie grondt in de redelijkheidsnotie die ten grondslag ligt aan ons communicatieve handelen, waar Rawls het politieke liberalisme in reflectief evenwicht laat balanceren met het door een ieder gedeelde begrip van de samenleving als een systeem van samenwerking tussen vrije en gelijke burgers, daar zwijgt Pettit. Hier en daar vinden we een verwijzing naar Rawls' methode van het reflectief evenwicht, maar Pettit geeft het niet echt handen en voeten. Hij lijkt vooral te vertrouwen op de politieke aantrekkingskracht die van het republikeinse ideaal zelf uitgaat.

Maar misschien laat Pettit een wijsgerige onderbouwing achterwege omdat hij het voor onmogelijk houdt om een verdediging van een staatsvorm te vinden waarmee ieder redelijk mens het op dezelfde gronden eens zou moeten zijn. De republikeinse traditie lijkt daarvoor immers een veel te realistische insteek te kennen. Aristoteles bijvoorbeeld verdedigde de gemengde staatsvorm al omdat dat acceptabel zou kunnen zijn voor democraten én oligarchen. Geen rationele consensus dus, maar politiek compromis. Dat Machiavelli er een realistische optiek op nahoudt, behoeft geen betoog. Pettit maakt echter geen werk van het politieke realisme dat aan het republikanisme vastgeklonken lijkt en laat zo een interessante verdedigingslinie van het republikanisme links liggen. 